\title{
The Effect of Mangosteen Rind Extract (Garcinia mangostana L.) Toward Stress Oxidative Parameter, Leukocytes, Leukocytes Type Counts on Male Rats (Rattus norvegicus) with Excessive Physical Activity
}

\author{
Rika Nailuvar Sinaga*, Zulaini Zulaini \\ Department of Sport Sciences, Faculty of Sport Sciences, Universitas Negeri Medan, Medan, Indonesia
}

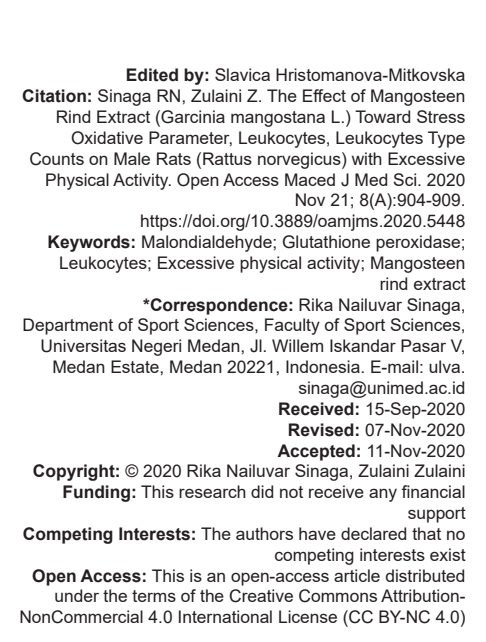

Abstract

BACKGROUND: Excessive and heavy physical activity could lead to the oxidative stress in the body. This condition can affect several blood parameters such as malondialdehyde (MDA), glutathione peroxidase (GPx), leukocytes, and its type counts. One way to overcome the effects of oxidative stress due to strenuous physical activity is by giving natural antioxidants. Mangosteen rind (Garcinia mangostana L.) contains considerable antioxidants, namely, xanthones and procyanidin.

AIM: This research aimed to investigate the effect of mangosteen rind extract (MRE) on oxidative stress parameters, leukocyte count, and leukocyte count in male rats (Rattus norvegicus) that received excessive physical activity.

METHODS: This study was purely experimental research with a post-test only control group design, using 29 white rats $(R$. norvegicus) as experimental animals, which were divided into four groups. The first group (P1) received distilled water and the other group received MRE at a dose of $50 \mathrm{mg} / \mathrm{KgBW}$ (Body Weight) (P2), $100 \mathrm{mg} / \mathrm{KgBW}$ (P3), and $200 \mathrm{mg} / \mathrm{KgBW}$ (P4) for 3 weeks, respectively. Swimming as a physical activity was carried out 3 times a week in all groups. Examination of leukocyte count and species was carried out on the last day of treatment after the rats swam to fatigue.

RESULTS: MDA levels did not decrease significantly while GPx activity increased significantly. Moreover, the average leukocytes and lymphocytes showed a decrease but not significant. A significant decrease in the percentage of neutrophils and basophils was obtained by P4 group compared to others. In addition, a significant decrease in the average percentage of eosinophils for P3 and P4 groups was obtained. Furthermore, P3 and P4 group exhibit significant increase of the average percentage of monocytes.

CONCLUSION: MRE as an antioxidant affects the levels of neutrophils, basophils, eosinophils, and monocytes but not in MDA, GPx, leukocytes, and lymphocytes.

\section{Introduction}

It is generally known that exercise can have both positive and negative impact on the body. Exercise that is properly and regularly performed can prevent some chronic diseases. However, an excessive exercise can trigger oxidative stress due to an imbalance between reactive oxygen species (ROS) and antioxidants of the body [1], [2]. During exercise, the increased activity of muscle contraction leads to an increase in ROS production [3] and under the conditions of oxidative stress, ROS causes lipid peroxidation in cell membranes [4]. Then, malondialdehyde (MDA) is resulted because of lipid peroxidation that is caused by free radicals during physical exercise. Therefore, many studies used MDA as a measure of oxidative stress [2]. The previous studies have suggested that aerobic exercise increases MDA levels in both trained and untrained samples [5].
Body has a defense mechanism against ROS, namely, enzymatic and non-enzymatic antioxidants. Enzymatic antioxidants are important defense antioxidants, where the main function is carried out by superoxide dismutase (SOD), catalase (CAT), and glutathione peroxidase (GPx). SOD converts superoxide radicals to $\mathrm{H}_{2} \mathrm{O}_{2}$, which is catalyzed to be $\mathrm{H}_{2} \mathrm{O}$ through the action of CAT and GPx. GPx can also be an electron donor to reduce peroxidase [6]. In the oxidative stress state of the body's endogenous antioxidants, it decreases as the results of a previous study which stated that GPx activity dropped significantly $15 \mathrm{~min}$ after anaerobic exercise [7].

Oxidative stress can also affect the immunity. Research results showed that oxidative stress due to the physical activity resulted in decreased immunity [8] and changes in leukocyte values [9]. The effect of exercise on leukocyte values and leukocyte counts has been observed by several researchers before. 
Severe physical exercise in untrained people causes leukocytosis, lymphocytosis, neutropenia, and monocytopenia [10]. Other research's also found that strenuous physical exercise performed on athletes and not athletes causes leukocytosis, neutrophilia, and monocytosis [11].

It is not yet fully known whether the disturbance of the balance between free radicals and endogenous antioxidants in the body causes the need for the consumption of exogenous antioxidants. More than $40 \%$ of people who do exercise are taking antioxidant supplements to maintain health [12]. Antioxidant supplements consist of both synthetic and natural ingredients. The advantages of using natural antioxidants are that they have smaller and less expensive side effects. Various studies of antioxidant-rich medicinal plants were carried out to prevent oxidative stress from physical activity. Some studies that have been studied include lycopene from tomatoes, rhodiola rosea, grape seed extract, ginger, ixora parviflora, dragon fruit, and red fruit oil [13], [14], [15], [16], [17], [18], [19].

This research utilized mangosteen rind extract (MRE) as an exogenous antioxidant, as it is well known that mangosteen peel contains high antioxidants, namely, Xanthones and Procyanidin [20], [21]. Research on the efficacy of mangosteen rind is currently limited to health and only a little number of researches was performed in sport sciences. Based on the above explanation, this study focused on the effect of MRE on MDA as a marker of oxidative stress, the activity of GPx, leukocytes, and the count of leukocytes in male rats (Rattus norvegicus) which were treated with excessive physical activity.

The results of this study are expected to contribute to science and technology, as well as becoming the basis for further research and development in the use of natural plants to improve public health, especially athlete health. Moreover, the results of this study can be applied to athletes after further development so that they can be consumed during training programs or during competitions that can support development programs in the field of sports achievement and health.

\section{Methods}

This research is purely experimental with a post-test-only control group research design. The samples in this research were 29 male white rats ( $R$. norvegicus), 2 months old with a body weight of 180-200 g. Rats were acclimatized for 1 week in experimental animal's cage and given food and drink to their heart's content. Room light was controlled exactly $12 \mathrm{~h}$ bright (06.00-18.00) and 12 $\mathrm{h}$ dark (18.00-06.00), while the temperature and humidity of the room were left in the natural range. For the use and handling of experimental animals, this research has received "Ethical clearance" from the ethics committee of FMIPA-Universitas Sumatera Utara, Indonesia (approval number 0012/ KEPH-FMIPA/2018).

The sample was divided into four groups, the first group (P1) which is referred as a control group was treated with distilled water only. Then, the second (P2), third (P3), and fourth (P4) groups were treated with (MRE) at a dose of $50 \mathrm{mg} / \mathrm{kgBW}, 100 \mathrm{mg} / \mathrm{kgBW}$, and $200 \mathrm{mg} / \mathrm{KgBW}$, respectively. All samples were subjected to the excessive physical activity. All samples swam as hard as possible until almost drowning or showing visible signs of fatigue in the form of sinking almost all of the body except the nose and weakening of limb movements. Swimming was done 3 times a week for $30 \mathrm{~min}$ (Week I), $35 \mathrm{~min}$ (Week II), and $40 \mathrm{~min}$ (Week III).

MRE was made by maceration method using concentrated ethanol $96 \%$. The mangosteen fruit was obtained from local farmers. The mangosteen rind was first peeled, washed, and cut into small pieces and dried in a drying cabinet. After drying, it was smoothed using a blender machine to produce mangosteen rind powder. MRE was isolated by maceration method using ethanol (96\%) which has been distilled 10 times of the weight of mangosteen rind powder. Ethanol was added into a mangosteen rind powder in a container with a ratio of $1: 7$ (powder:ethanol), and then the mixture was left for 3 days then filtered and closed tightly. The maceration results were collected in a container then processed by a rotary evaporator at a temperature of $45^{\circ} \mathrm{C}$ until the extract was thickened. The less thickened extract was then evaporated in a water bath until a thick extract was finally obtained. Then, as much as $100 \mathrm{mg}$ of MRE was mashed using a pestle and mortar to obtain a fine extract. After that, $0.5 \%$ carboxymethylcellulose (CMC) solution was added slowly and ground until a homogeneous phase was reached. Finally, the suspension was added to the $10 \mathrm{~mL}$ volumetric flask until it reaches the mark line. The extract was given every day, 30 min before the swimming activity.

Blood tests to measure levels of MDA, GPx, leukocytes, and count types were carried out on the last day of treatment after the rats swam to exhaustion. Rats were turned off and their blood was taken from the heart. MDA and GPx measurements were carried out by the enzyme-linked immune sorbent assay (ELISA) method at a wavelength of $450 \mathrm{~nm}$, while leukocytes and type count were conducted through the Hematology Analyzer method. Finally, the data obtained were tested by ANOVA analysis and followed by LSD and Kruskal-Wallis and Mann-Whitney test. In this study, the statistical test decision was taken to be significant with $P<0.05$. 


\section{Results}

Research has been conducted with the aim to see the antioxidant potential of mangosteen peel extract (Garcinia mangostana L.) on levels of MDA, GPx, leukocytes, and count types.

Table 1: The MDA level of samples in various groups

\begin{tabular}{|c|c|c|c|c|c|}
\hline \multirow{2}{*}{ Parameter } & \multicolumn{4}{|l|}{ Group } & \multirow{2}{*}{$p$-value } \\
\hline & $\overline{\mathrm{P} 1}$ & P2 & P3 & P4 & \\
\hline $\mathrm{MDA}(\mathrm{nmol} / \mathrm{mL})$ & $0.659 \pm 0.09$ & $0.657 \pm 0.06$ & $0.611 \pm 0.01$ & $0.572 \pm 0.18$ & 0.134 \\
\hline
\end{tabular}

Based on Tables 1 and 2, the high average MDA was found in the P1 group, while non-significant decrease was pointed by other groups. The average GPx experienced an increase with the highest average was found in the group who received a dose of $200 \mathrm{mg} / \mathrm{KgBW}$ (P4). However, this increase is insignificant.

Table 2: The GPx level of samples in various groups

\begin{tabular}{llllll}
\hline Parameter & Group & \multicolumn{3}{l}{} & p-value \\
\cline { 2 - 5 } & $\mathrm{P} 1$ & $\mathrm{P} 2$ & $\mathrm{P} 3$ & $\mathrm{P} 4$ & \\
\hline $\mathrm{GPx}(\mathrm{mU} / \mathrm{mL})$ & $47.60 \pm 12.61$ & $48.04 \pm 9.39$ & $48.69 \pm 8.19$ & $49.16 \pm 17.71$ & 0.996 \\
\hline
\end{tabular}

Based on the difference of leukocyte count of the sample described in Table 3, it can be seen that the control group (P1) obtained the highest average leukocytes count with a decreasing trend along with the increasing of MRE dosages.

Table 3: The leukocytes count difference of samples in various groups

\begin{tabular}{llllll}
\hline Parameter & Group & & & p-value \\
\cline { 2 - 5 } & $\mathrm{P} 1$ & $\mathrm{P} 2$ & $\mathrm{P} 3$ & $\mathrm{P} 4$ & \\
\hline Leukocytes $\left(10^{9} / \mathrm{l}\right)$ & $11.23 \pm 4.95$ & $10.22 \pm 4.70$ & $9.86 \pm 5.84$ & $8.30 \pm 2.65$ & 0.713 \\
\hline
\end{tabular}

In Table 4, a significant decrease of neutrophil, eosinophil, and basophile was obtained, while the nonsignificant decrease was assigned to lymphocytes and significant increase was found for the monocytes.

Table 4: The leukocytes type count of samples in various groups

\begin{tabular}{llllll}
\hline Parameter & Group & & & p-value \\
\cline { 2 - 5 } & $\mathrm{P} 1$ & $\mathrm{P} 2$ & $\mathrm{P} 3$ & $\mathrm{P} 4$ & \\
\hline Neutrophil (\%) & $13.42 \pm 3.50$ & $11.14 \pm 7.40$ & $6.62 \pm 4.03$ & $4.00 \pm 2.23$ & $0.005^{\star}$ \\
Eosinophil (\%) & $3.14 \pm 1.57$ & $1.57 \pm 1.51$ & $1.13 \pm 1.72$ & $0.71 \pm 0.48$ & $0.025^{\star}$ \\
Basophile(\%) & $2.71 \pm 0.75$ & $2.00 \pm 2.76$ & $0.38 \pm 0.51$ & $0.14 \pm 0.37$ & $0.001^{*}$ \\
Lymphocytes (\%) & $77 \pm 2.82$ & $75.71 \pm 10.93$ & $74.38 \pm 9.84$ & $70.43 \pm 9.10$ & 0.909 \\
Monocytes (\%) & $3.71 \pm 2.98$ & $9.57 \pm 11.37$ & $12.25 \pm 4.20$ & $13.71 \pm 2.49$ & $0.001^{*}$ \\
\hline
\end{tabular}

Figure 1 shows that the administration of MRE at a dose of $200 \mathrm{mg} / \mathrm{KgBW}$ gave a better decrease in the percentage of neutrophils compared to others. This

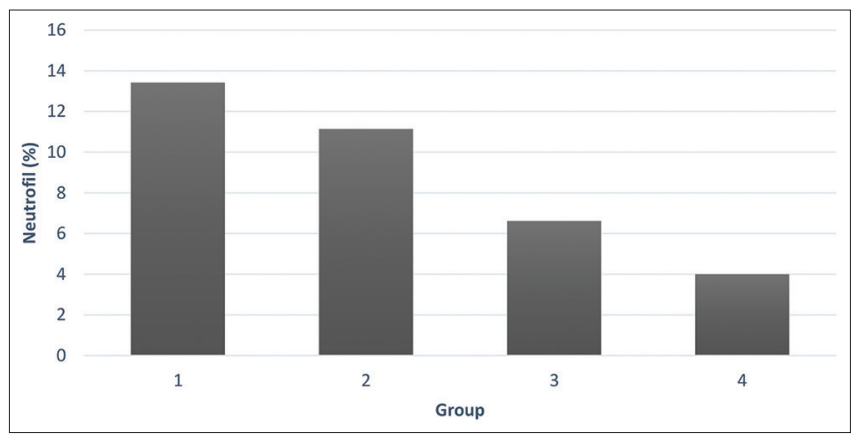

Figure 1: The comparison of neutrophil in every group was obtained from the LSD test results where significant differences were found between the $\mathrm{P} 1$ treatment groups compared to the P3 and P4 groups $(P<0.05)$. Furthermore, there were significant differences between groups P2 and P4 $(P<0.05)$.

Figure 2 reveals that giving $200 \mathrm{mg} / \mathrm{KgBW}$ of MRE gave a better reduction in basophil percentage compared to a dose of $50 \mathrm{mg} / \mathrm{KgBB}$ and $100 \mathrm{mg} / \mathrm{KgBB}$. This was obtained from the Mann-Whitney test results where significant differences were found between the $\mathrm{P} 1$ treatment groups compared to the P2, P3, and P4 groups $(P<0.05)$. There were significant differences between groups P2 and P4 $(P<0.05)$ as well.

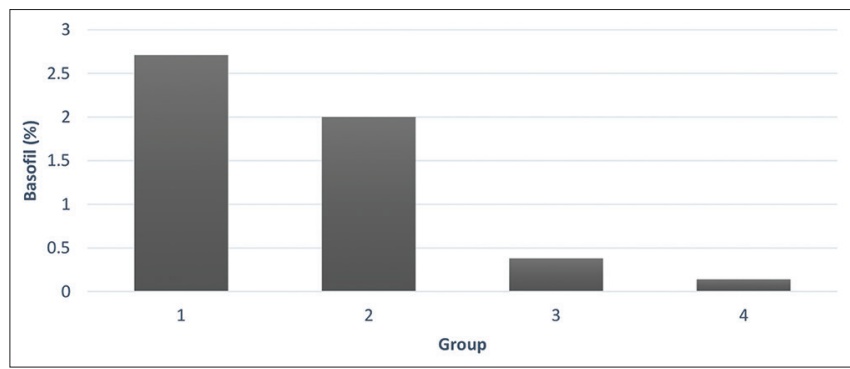

Figure 2: The comparison of basophile in every group

In Figure 3, giving MRE with doses of $100 \mathrm{mg} / \mathrm{KgBW}$ and $200 \mathrm{mg} / \mathrm{KgBW}$ both provide a better reduction in eosinophil percentage. This was obtained from the Mann-Whitney test results where significant differences were found between the $\mathrm{P} 1$ treatment groups compared to the P3 and P4 groups $(P<0.05)$.

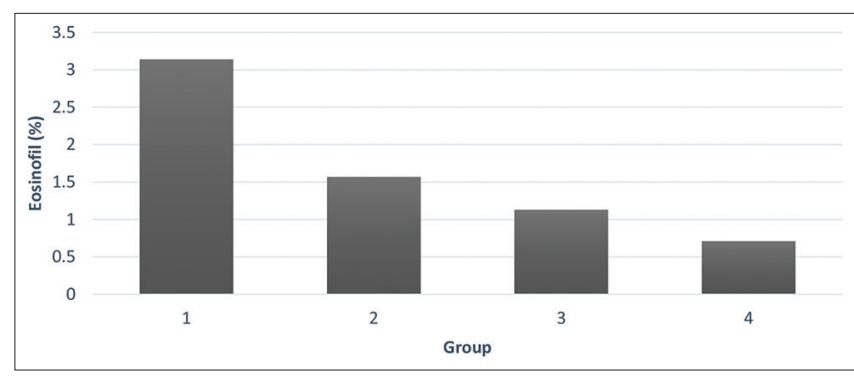

Figure 3: The comparison of eosinophil in every group

Finally, Figure 4 describes that MRE with doses of $100 \mathrm{mg} / \mathrm{kgBB}$ and $200 \mathrm{mg} / \mathrm{kgBB}$ both increase the percentage of monocytes. This was obtained from the Mann-Whitney test results where significant differences were found between the P1 treatment groups compared with the $\mathrm{P} 3$ and $\mathrm{P} 4$ groups $(P<0.05)$. There was a significant difference between

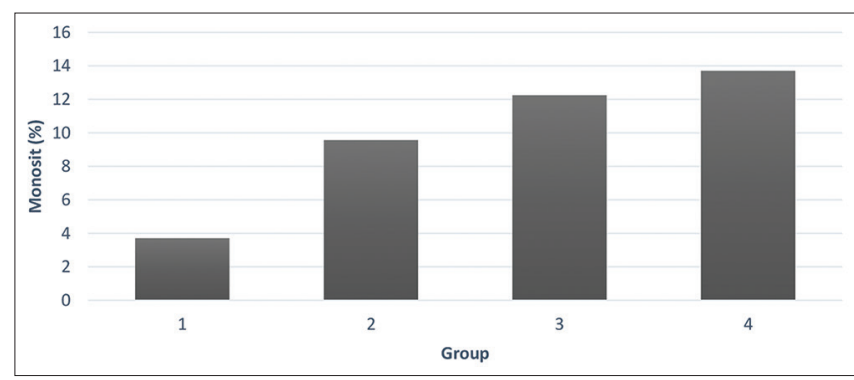

Figure 4: The comparison of monocytes in every group 
the P2 treatment group compared to the P3 and P4 groups $(P<0.05)$.

\section{Discussion}

The results of this research indicate differences in MDA levels as indicators of oxidative stress and GPx as enzymatic antioxidants after toward excessive physical activity. MDA levels experienced a significant decrease while GPx activity gave a significant increase. Previous research on the effect of exercise on MDA and GPx activities has been carried out. MDA levels increased significantly in untrained individuals who receive aerobic and anaerobic exercise [22]. The increasing in MDA levels can be categorized as an indicator of oxidative stress that is results from lipid peroxidation. Lipid peroxidation occurs because of hydroxyl radicals react with unsaturated fatty acids and forms lipid peroxyl radicals. Moreover, reduced membrane fluidity, cell swelling, inability to maintain ionic gradients occur in cells due to lipid peroxidation [23], [24]. Ebele et al. (2016) and Berzosa et al. (2011) found that strenuous physical exercise significantly decreased GPx activity [25], [26]. Thirurmalai et al. (2011) found that GPx activity dropped significantly in the skeletal muscles of rats that were stretched to exhaustion [27]. This GPx activity is considered significant as it is an enzyme that reduces $\mathrm{H}_{2} \mathrm{O}_{2}$ to $\mathrm{H}_{2} \mathrm{O}$ by oxidizing glutathione (GSH) [28].

The administration of MRE showed a significant decrease for MDA levels and an increase in GPx levels. Mangosteen rind has a bioactive component that acts as an antioxidant that can prevent oxidative damage, namely, xanthones, flavonoids, and proanthocyanidins [29]. Furthermore, MRE significantly inhibits the production of $\mathrm{H}_{2} \mathrm{O}_{2}$-induced ROS in cells [30].

The results showed that the average leukocyte count in the control group was higher than the group that received mangosteen rind extract. Physical activity affects the value of leukocytes as in the previous studies which found that physical activity of moderate intensity increases the average leukocyte count [31]. Moreover, physical exercise increases the average of white blood cells, compared to between before and after physical exercise [32]. Other researchers argue that the increase in the number of leukocytes due to heavy physical activity which trigger the number of free radicals exceeding the ability of antioxidant defense capacity. This imbalance can cause oxidative stress which can ultimately stimulate the activity of leukocytes cells [33].

However, the average leukocyte count decreased in the group that received MRE even though the difference was not significant. MRE has the potential as an antioxidant [34], where the antioxidant activity of mangosteen rind will reduce oxidative stress so that the stimulation of leukocyte cell activity is reduced.
The same thing is applied to leukocyte counts. The percentage of neutrophils and basophils showed a decrease in the group that received MRE with the optimum dosage of $200 \mathrm{mg} / \mathrm{KgBW}$ to result the best reduction in the percentage of neutrophils and basophils. Furthermore, the percentage of eosinophils decreased in the group that received mangosteen rind extract. However, both dosages of $100 \mathrm{mg} / \mathrm{KgBW}$ and $200 \mathrm{mg} / \mathrm{KgBB}$ gave the best decrease in eosinophil percentage. Finally, the lymphocyte percentage also decreased in the group that received MRE but was not found to be significant.

In contrast to the monocytes, the percentage of monocytes increased in the group that received mangosteen rind extract. Several studies have been conducted to see the effect of physical activity on monocytes. Heavy exercise can increase monocyte concentration in untrained people [11]. This increase was due to acute response to exercise to changes in hemodynamic blood vessels or changes in monocyte interactions in endothelial cells mediated by catecholamines [31]. Therefore, the increase in monocytes percentage because of MRE need further research to investigate.

Previously, Sinaga and Susanti (2020), found that red fruit oil can reduce MDA levels, increase GPx, and endurance and delay fatigue induced by maximal physical activity in mice [35]. The results of recent studies related to the benefits of mangosteen fruit in the field of sports found that concentrated mangosteen drink can increase GPx and CAT activity, reduce oxidative stress in muscles, and increase lactate clearance, and hence are beneficial for reducing muscle fatigue after exercise. This study was conducted on a sample of mice that received exercise was running on a treadmill [36]. Whereas in our study, it was not only observing effect of mangosteen rind on oxidative stress conditions that occurred due to exercise but also assessing the changes in body immunity from leukocytes and their type count.

The results of this study indicate that the MRE influences the counts of types of leukocytes that play a role in body immunity. Provision of MRE which is further developed can be suggested for consumption by athletes who are prone to immune disorders due to strenuous exercise so that it can support athlete's performance and health.

\section{Conclusion}

It can be concluded that the extract of mangosteen rind (G. mangostana L.) as an antioxidant affects changes in the number of leukocytes counts but not for lymphocytes, leukocytes, MDA, and GPx in male rats ( $R$. norvegicus) which were treated with excessive physical activity. 


\section{Acknowledgment}

The authors would like to thank Rector of Universitas Sumatera Utara for allowing the utilization of Integrated Laboratory, Faculty of Medicine, Universitas Sumatera Utara as the research facility.

\section{Ethical Clearance}

This research has received "Ethical Clearance" from the ethics committee of FMIPA-Universitas Sumatera Utara, Indonesia (approval number 0012/ KEPH-FMIPA/2018).

\section{References}

1. Marius-Daniel R, Dragomir C, Stelian S. The effect of acute physical exercise on liver and kidney in the Wistar rat. Rom Biotechnol Lett. 2010;15(3):51-5.

2. Urso ML, Clarkson PM. Oxidative stress, exercise, and antioxidant supplementation. Toxicology. 2003;189(1-2):41-54. https://doi.org/10.1016/s0300-483x(03)00151-3 PMid:12821281

3. Powers SK, Jackson MJ. Exercise-induced oxidative stress: Cellular mechanisms and impact on muscle force production. Physiol Rev. 2008;88(4):1243-76. https://doi.org/10.1152/ physrev.00031.2007

PMid:18923182

4. Evans WJ. Vitamin E, Vitamin C, and exercise. Am J Clin Nutr. 2000;72(2 Suppl):647S-52. PMid:10919971

5. Algul S, Ugras S, Kara M. Comparative evaluation of MDA levels during aerobic exercise in young trained and sedentary male subjects. East J Med. 2018;23:98-101. https://doi.org/10.5505/ ejm.2018.40469

6. Duracková Z. Some current insights into oxidative stress. Physiol Res. 2010;59(4):459-69.

PMid:19929132

7. Wiecek M, Szymura J, Maciejczyk M, Kantorowicz M, Szygula Z. Anaerobic exercise-induced activation of antioxidant enzymes in the blood of women and men. Front Physiol. 2018;9:1006. https://doi.org/10.3389/fphys.2018.01006 PMid:30140236

8. Nieman DC, Henson DA, Austin MD, Brown VA. Immune response to a 30-minute walk. Med Sci Sports Exerc. 2005;37(1):57-62. https://doi.org/10.1249/01.MSS.0000149808.38194.21 PMid:15632669

9. Senturk UK, Yalcin O, Gunduz F, Kuru O, Meiselman HJ, Baskurt OK. Effect of antioxidant vitamin treatment on the time course of hematological and hemorheological alterations after an exhausting exercise episode in human subjects. $J$ Appl Physiol. 2005;98(4):1272-9. https://doi.org/10.1152/ japplphysiol.00875.2004 PMid:15579575
10. Sodique NO, Enyikwola O, Ekanem AU. Exercise-induced leucocytosis in some healthy adult Nigerians. Afr J Biomed Res. 2000;3:85-8

11. Risøy $B$, Raastad T, Hallén J, Lappegård KT, Bæverfjord $K$, Kravdal A, et al. Delayed leukocytosis after hard strength and endurance exercise: Aspects of regulatory mechanisms. BMC Physiol. 2003;3:14. https://doi.org/10.1186/1472-6793-3-14 PMid:14667246

12. Bucioli SA, De Abreu LC, Valenti VE, Leone C, Vannucchi H. Effects of Vitamin E supplementation on renal non-enzymatic antioxidants in young rats submitted to exhaustive exercise stress. BMC Complement Altern Med. 2011;11:133. https://doi. org/10.1186/1472-6882-11-133 PMid:22185374

13. Liu CC, Huang CC, Lin WT, Hsieh CC, Huang SY, Lin SJ et al. Lycopene supplementation attenuated xanthine oxidase and myeloperoxidase activities in skeletal muscle tissues of rats after exhaustive exercise. Br J Nutr. 2005;94(4):595-601. https://doi.org/10.1079/bjn20051541 PMid:16197586

14. Parisi A, Tranchita E, Duranti G, Ciminelli E, Quaranta F, Ceci R, et al. Effects of chronic Rhodiola rosea supplementation on sport performance and antioxidant capacity in trained male: Preliminary results. J Sports Med Phys Fitness. 2010;50(1):57-63. PMid:20308973

15. Belviranli M, Gökbel H, Okudan N, Başarali K. Effects of grape seed extract supplementation on exercise-induced oxidative stress in rats. $\mathrm{Br} \mathrm{J}$ Nutr. 2012;108(2):249-56. https://doi. org/10.1017/s0007114511005496 PMid:22011589

16. Rosidi A, Khomsan A, Setiawan B, Riyadi H, Briawan D. Effect of temulawak (Curcumin xanthorrhiza Roxb) extract on reduction of MDA (Malondialdehyde) levels of football athletes. Pak J Nutr. 2013;12:842-50. https://doi.org/10.3923/pjn.2013.842.850

17. Kan NW, Huang WC, Lin WT, Huang CY, Wen KC, Chiang HM, et al. Hepatoprotective effects of Ixora parviflora extract against exhaustive exercise-induced oxidative stress in mice. Molecules. 2013;18(9):10721-32. https://doi.org/10.3390/ molecules 180910721 PMid:24005966

18. Harahap NS, Amelia R. Red dragon fruit (Hylocereus polyrhizus) extract decreases lactic acid level and creatine kinase activity in rats receiving heavy physical exercise. Open Access Maced J Med Sci. 2019;7(14):2232-5. https://doi.org/10.3889/ oamjms.2019.626 PMid:31592070

19. Sinaga FA, Susanti N. The influence of red fruit (Pandanus conoideus Lam.) oil on glutathione peroxidase level at maximum physical activity. Asian J Pharm Clin Res. 2018;11(13):104-6. https://doi.org/10.22159/ajpcr.2018.v11s1.26579

20. Tousian Shandiz H, Razavi BM, Hosseinzadeh H. Review of Garcinia mangostana and its xanthones in metabolic syndrome and related complications. Phyther Res. 2017;31(8):1173-82. https://doi.org/10.1002/ptr.5862 PMid:28656594

21. Zhang M, Sun J, Chen P. A computational tool for accelerated analysis of oligomeric proanthocyanidins in plants. J Food Compos Anal. 2017;56:124-33. https://doi.org/10.1016/j. jfca.2016.11.014

22. Park SY, Kwak YS. Impact of aerobic and anaerobic exercise training on oxidative stress and antioxidant defense in athletes. J Exerc Rehabil. 2016;12:113-8. https://doi.org/10.12965/ jer.1632598.299

PMid:27162773 
23. Alessio HM. Exercise-induced oxidative stress. Med Sci Sports Exerc. 1993;25:218-24.

PMid:8383786

24. Okafor OY, Erukainure OL, Ajiboye JA, Adejobi RO, Owolabi FO, Kosoko SB. Modulatory effect of pineapple peel extract on lipid peroxidation, catalase activity and hepatic biomarker levels in blood plasma of alcohol-induced oxidative stressed rats. Asian Pac J Trop Biomed. 2011;1(1):12-4. https://doi.org/10.1016/ s2221-1691(11)60060-9

PMid:23569717

25. Ebele IJ, Jenniger IA, Nnabugo EC, Sidney OI, Chibuike OK, Chukwuma OO, et al. Oxidative stress/lipid peroxidation and antioxidant enzymes in apparently healthy individuals involved in physical exercise. Asian J Med Sci. 2016;7:16-9. https://doi. org/10.3126/ajms.v7i6.15245

26. Berzosa C, Cebrian I, Fuentes-Broto L, Gomez-Trullen E, Piedrafita E, Martinez-Ballarin E, et al. Acute exercise increases plasma total antioxidant status and antioxidant enzyme activities in untrained men. J Biomed Biotechnol. 2011;2011:540458. https://doi.org/10.1155/2011/540458

PMid:21436993

27. Thirumalai T, Therasa SV, Elumalai EK, David E. Intense and exhaustive exercise induce oxidative stress in skeletal muscle. Asian Pac J Trop Dis. 2011;1(1):63-6. https://doi.org/10.1016/ S2222-1808(11)60016-9

28. Mazzetti I, Grigolo B, Pulsatelli L, Dolzani P, Silvestri T, Roseti L, et al. Differential roles of nitric oxide and oxygen radicals in chondrocytes affected by osteoarthritis and rheumatoid arthritis. Clin Sci (Lond). 2001;101(6):593-9. https://doi.org/10.1042/cs20010030 PMid: 11724645

29. Fu C, Loo AE, Chia FP, Huang D. Oligomeric proanthocyanidins from mangosteen pericarps. J Agric Food Chem.
2007;55(19):7689-94. https://doi.org/10.1021/jf071166n PMid: 17715900

30. Jaisupa N, Moongkarndi P, Lomarat P, Samer J, Tunrungtavee V, Muangpaisan $\mathrm{W}$, et al. Mangosteen peel extract exhibits cellular antioxidant activity by induction of catalase and heme oxygenase-1 mRNA expression. J Food Biochem. 2018;42:e12511. https://doi.org/10.1111/jfbc.12511

31. Irianti E, Ardinata D. Pengaruh aktivitas fisik sedang terhadap hitung lekosit dan hitung lekosit pada orang tidak terlatih. Maj Kedokt Nusant. 2008;41:259-66.

32. Bhatti R, Shaikh DM. The effect of exercise on blood parameters. Pak J Physiol. 2007;3(2):1.

33. Nieman DC. Exercise effects on systemic immunity Immunol Cell Biol. 2000;78:496-501. https://doi. org/10.1111/j.1440-1711.2000.t01-5-.x

34. Moongkarndi $\mathrm{P}$, Kosem $\mathrm{N}$, Kaslungka $\mathrm{S}$, Luanratana $\mathrm{O}$, Pongpan N, Neungton N. Antiproliferation, antioxidation and induction of apoptosis by Garcinia mangostana (mangosteen) on SKBR3 human breast cancer cell line. J Ethnopharmacol. 2004;90(1):161-6. https://doi.org/10.1016/j.jep.2003.09.048 PMid: 14698525

35. Sinaga FA, Purba PH, Sinaga RN, Silaban R. Effects of red fruit (Pandanus conoideus Lam) oil on exercise endurance and oxidative stress in rats at maximal physical activity. Open Access Maced J Med Sci. 2020;8(A):164-9. https://doi.org/10.3889/ oamjms.2020.3428.

36. Chang CC, Chen CW, Owaga E, Lee WT, Liu TN, Hsieh RH Mangosteen concentrate drink supplementation promotes antioxidant status and lactate clearance in rats after exercise. Nutrients. 2020;12(5):1447. https://doi.org/10.3390/ nu12051447

PMid:32429510 